\title{
Preparation and characterization of a chitosan film with grape seed extract- carvacrol microcapsules and its effect on the shelf-life of refrigerated Salmon (Salmo salar)
}

\author{
Vera L.C.D. Alves ${ }^{\mathrm{a}}$, Bruna P.M. Rico ${ }^{\mathrm{a}}$, Rui M.S. Cruz ${ }^{\mathrm{a}, \mathrm{d}, \mathrm{e}}$, António A. Vicente ${ }^{\mathrm{c}}$, Igor Khmelinskii ${ }^{\mathrm{b}, \mathrm{e}}$, \\ Margarida C. Vieira ${ }^{\mathrm{a}, \mathrm{d}, *}$ \\ ${ }^{a}$ Department of Food Engineering, Institute of Engineering, University of Algarve, Faro, Portugal \\ ${ }^{\mathrm{b}}$ Department of Chemistry and Pharmacy, Faculty of Science and Technology, University of Algarve, Faro, Portugal \\ ${ }^{c}$ CEB- Centre for Biological Engineering, Universidade do Minho, Campus de Gualtar, 4710-057 Braga, Portugal \\ ${ }^{\mathrm{d}}$ MeditBio- Centre for Mediterranean Bioresources and Food, Faculty of Sciences and Technology, University of Algarve, Faro, Portugal \\ e CIQA-Chemistry Research Centre of Algarve, Faculty of Sciences and Technology, University of Algarve, Faro, Portugal
}

\section{A R T I C L E I N F O}

\section{Keywords:}

Active packaging

Microencapsulation

Polyphenol

Essential oil

Fish

\begin{abstract}
A B S T R A C T
Chitosan films with grape seed extract and carvacrol microcapsules (CMF) were prepared and their physicochemical properties and effect on physico-chemical and microbiological parameters in refrigerated salmon were tested. CMF showed higher values of thickness $(0.41 \pm 0.04 \mathrm{~mm})$, moisture content $(13 \pm 1 \mathrm{~g}$ water/100 g film), $a(11 \pm 3), b(12 \pm 3)$, opacity $(20 \pm 1 \%)$, water vapor permeability (WVP) $(4.4 \pm 0.4) \times 10^{-10}$ $\mathrm{gPa}^{-1} \mathrm{~s}^{-1} \mathrm{~m}^{-1}$, oxygen permeability $\left(\mathrm{O}_{2} \mathrm{P}\right)(1.3 \pm 0.3) \times 10^{-12} \mathrm{gPa}^{-1} \mathrm{~s}^{-1} \mathrm{~m}^{-1}$ and carbon dioxide permeability $\left(\mathrm{CO}_{2} \mathrm{P}\right)(1.3 \pm 0.3) \times 10^{-12} \mathrm{gPa}^{-1} \mathrm{~s}^{-1} \mathrm{~m}^{-1}$ as compared to those of the chitosan control film (CCF). CMF showed lower values of $L(66 \pm 5)$ and water solubility $(17 \pm 1 \%)$.

The salmon packed into CMF presented on the 7th day of storage a lower value of TVB-N (37 $\pm 4 \mathrm{mg} \mathrm{N} /$ $100 \mathrm{~g}$ fish) as compared to the CCF (42 $\pm 3 \mathrm{mg} \mathrm{N} / 100 \mathrm{~g}$ fish) and control samples (CS; $66 \pm 7 \mathrm{mg} \mathrm{N} / 100 \mathrm{~g}$ fish). The CMF showed lower values of $\mathrm{pH}$ and lightness after 7 days of storage as compared to CS and CCF. The CMF showed also lower values of mesophilic and psychrophilic bacteria and Pseudomonas spp, reaching the maximum limit allowed for the first two only on the 7th day of storage.

CMF increases the shelf-life of refrigerated salmon to 4-7 days of storage due to the antimicrobial effect of the natural agents.
\end{abstract}

\section{Introduction}

It is important to find suitable materials in order to improve the efficiency and stability of packaging films produced from natural sources. Packaging films may be produced using different types of compounds, such as polysaccharides, proteins and lipids, alone or combined in blends or layers (Flores-López, Cerqueira, Jasso de Rodríguez, \& Vicente, 2015). Chitosan (1,4-linked 2-amino-2-deoxy- $\beta$ D-glucan) is one of the most widely used natural compounds due to its characteristics such as high antimicrobial activity, biocompatibility, biodegradability and non-toxic profile. This polysaccharide was studied for application in different areas, such as food, pharmaceutical, medicine, agriculture, and environmental industries (Jiang, Deng, James, Nair, \& Laurencin, 2014; Pinheiro et al., 2010, pp. 18-28; Ruiz-Navajas,
Viuda-Martos, Sendra, Perez-Alvarez, \& Fernández-López, 2013).

Chitosan forms a transparent film with good mechanical properties, being an effective barrier to gases $\left(\mathrm{CO}_{2}\right.$ and $\left.\mathrm{O}_{2}\right)$, showing high permeability to water vapor and flexibility and resistance to breakage in different types of packages, therefore, it was used for improving the quality and extending the shelf-life of fresh and processed foods (Aizpurua-Olaizola et al., 2016; Corrales, Fernández, \& Han, 2014; Elsabee \& Abdou, 2013; Fabra, López-Rubio, \& Lagaron, 2014; Li, Li, Hu, \& Li, 2013; Rubilar, Cruz, Silva et al., 2013; Sansone et al., 2014; Sathivel, Liu, Huang, \& Prinyawiwatkul, 2007; Soares, Oliveira, \& Vicente, 2015).

Chitosan, due to its intrinsic properties, was also used to prepare microcapsules (Estevinho, Rocha, Santos, \& Alves, 2013; Hui et al., 2013; Song, Yu, Gao, Liu, \& Ma, 2013). Microencapsulation can be

\footnotetext{
* Corresponding author. Department of Food Engineering, Institute of Engineering, University of Algarve, Campus da Penha, 8005-139 Faro, Portugal; Center for Mediterranean Bioresources and Food (MeditBio), Faculty of Sciences and Technology, University of Algarve, Campus de Gambelas, 8005-139 Faro, Portugal.

E-mail address: mvieira@ualg.pt (M.C. Vieira).
} 

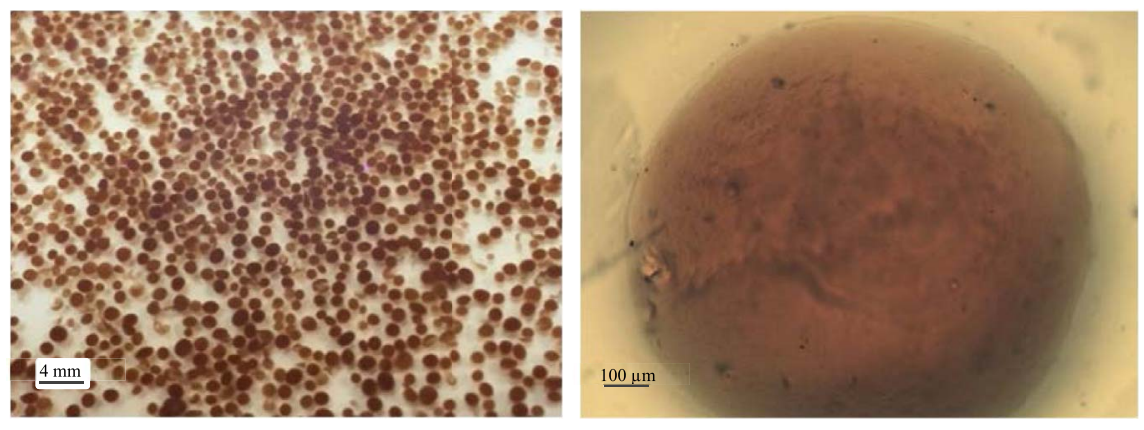

Fig. 1. Chitosan microcapsules with grape seed extract and carvacrol.

applied successfully to encapsulate natural compounds, such as essential oils and plant extracts, containing, for example, polyphenols with antimicrobial properties for use in food packaging (Nazzaro, Orlando, Fratianni, \& Coppola, 2012).

Microencapsulation with natural extracts can benefit from new materials or packaging methodologies, capable to extend the shelf-life of highly perishable fresh foods like vegetables, fruit, fish and meat, increasing their quality and safety (Aizpurua-Olaizola et al., 2016; Nazzaro et al., 2012).

This technology is used for stabilization of particles and protection and/or isolation of their active core material from the surroundings, allowing materials to be handled more easily for the application (Bansode, Banarjee, Gaikwad, Jadhav, \& Thorat, 2010). However, the degree of protection provided by microencapsulation is determined by the choice of the microencapsulation technique (Estevinho et al., 2013; Fabra et al., 2014; Fang \& Bhandari, 2012; Ma \& Sahai, 2013; Nesterenko, Alric, Silvestre, \& Durrieu, 2013; Rosa et al., 2013; Sansone et al., 2014).

Carvacrol is the major component of oregano (Origanum vulgare) essential oil ( $50-86 \mathrm{ml} / 100 \mathrm{ml}$ of oil) is a non-toxic phenolic monoterpene with proven antimicrobial activity against bacteria, fungi and yeasts and with insecticidal and anti-parasitic activity. It has high natural potential for preservation and safety of perishable foods (Costa et al., 2013; Hosseini, Rezaei, Zandi, \& Farahmandghavi, 2015a; Ramos, Beltrán, Peltzer, Valente, \& Garrigós, 2014; Rubilar, Cruz, Silva et al., 2013).

Grape seed extract is another interesting compound, rich in polyphenols such as catechin, epicatechin, gallic acid and proanthocyanidins. These polyphenolic compounds have various biological effects, including antimicrobial and antioxidant properties (Corrales et al., 2014; Li, Miao, Wu, Chen, \& Zhang, 2014; Li, Ai et al., 2013; Reddy et al., 2013; Rubilar, Cruz, Khmelinskii, \& Vieira, 2013; Rubilar, Cruz, Silva et al., 2013; Terra et al., 2007). Moreover, Rubilar, Cruz, Khmelinskii et al., (2013) reported synergistic antimicrobial and antioxidant effects by combining carvacrol, grape seed extract and chitosan against different spoilage microorganisms.

This study aimed to develop chitosan films with microcapsules of grape seed extract and carvacrol, their physico-chemical characterization, and study of their effect on the physico-chemical and microbiological parameters of refrigerated salmon.

\section{Materials and methods}

\subsection{Preparation of chitosan films with microcapsules}

\subsubsection{Preparation of chitosan film forming solution}

Chitosan films $1.25 \mathrm{~g} / 100 \mathrm{ml}$ were prepared according to Rubilar, Cruz, Silva et al. (2013) with some modifications. Chitosan film forming solution was prepared by dissolving $20 \mathrm{~g}$ of chitosan (Sigma-Aldrich) in $1000 \mathrm{ml}$ of glacial acetic acid (concentration of $1 \mathrm{ml}$ glacial acetic acid/ $100 \mathrm{ml}$ deionized water) (Panreac Química SA) and homogenized with an Ultra-Turrax homogenizer (T25, Ika-Labortechnick, Staufen,
Germany) at $9500 \mathrm{rpm}$ for $20 \mathrm{~min}$. The solution was kept at room temperature for $24 \mathrm{~h}$ at $20{ }^{\circ} \mathrm{C}$. Then, the chitosan solution was filtered through non-woven cheesecloth in order to remove any undissolved particles. After filtration the solution was stirred on a hot plate $\left(40{ }^{\circ} \mathrm{C}\right)$ and glycerol $(0.8 \mathrm{~g})$ was added to chitosan (for the final volume of $100 \mathrm{ml}$ ) and mixed for $30 \mathrm{~min}$. The chitosan solution was degassed in an ultrasonic bath (Bandelin Sonorex Super RX102H, Berlin, Germany) for $30 \mathrm{~min}$. Subsequently, $20 \mathrm{ml}$ of the chitosan solution was placed to dry in Petri dishes (dia $8.5 \mathrm{~cm}$, Normax) at a temperature of $20{ }^{\circ} \mathrm{C}$ during $48 \mathrm{~h}$.

\subsubsection{Preparation of microcapsules}

Based on the methods reported by Wu and Yao (2013) and Rubilar, Cruz, Silva et al., (2013), $3.48 \mathrm{ml}$ of Tween-80 (VWR) was added to the chitosan solution prepared in the previous section and mixed for $60 \mathrm{~min}$ at $40{ }^{\circ} \mathrm{C}$. Then, $34.2 \mathrm{~g}$ of grape seed extract (Groupe Grap SUD) and $3.2 \mathrm{ml}$ of carvacrol (Sigma-Aldrich) were added and mixed using an Ultra-Turrax homogenizer at $9500 \mathrm{rpm}$ for $30 \mathrm{~min}$. Finally, the solution was degassed in an ultrasonic bath (Bandelin Sonorex Super RX102H, Berlin, Germany) for $30 \mathrm{~min}$. Then, the chitosan solution with grape seed extract and carvacrol was added drop wise using a micro syringe (BD Micro-Fine, $0.3 \mathrm{~mm}$ internal diameter needle) to a sodium tripolyphosphate solution $(0.8 \mathrm{~g} / 100 \mathrm{ml}$ deionized water) (Sigma-Aldrich). The microcapsules were produced by ionic gelation during $30 \mathrm{~min}$ and, after the crosslinking time, were removed from the sodium tripolyphosphate solution and washed in distilled water (Fig. 1).

After $24 \mathrm{~h}$ of drying, $6.3 \mathrm{ml}$ of chitosan microcapsules were placed in the chitosan films (approx. 1400 microcapsules, $4.5 \mathrm{~cm}^{2}$ ). After drying, each film was cut and stored in desiccators at $25{ }^{\circ} \mathrm{C}$ and $57 \%$ relative humidity (obtained using a $\mathrm{NaBr}$ solution) until testing (Fig. 2).

\subsection{Determination of physico-chemical properties of the developed films}

\subsubsection{Film thickness}

The film thickness was determined with a digital micrometer (No. 293-5, Mitutoyo, Japan). Ten thickness measurements were taken randomly on each of the samples tested. The mean values were next used to calculate water vapor permeability (WVP), oxygen permeability $\left(\mathrm{O}_{2} \mathrm{P}\right)$ and carbon dioxide permeability $\left(\mathrm{CO}_{2} \mathrm{P}\right)$.

\subsubsection{Water solubility}

This parameter was determined according to the method reported by Cuq, Gontard, Cuq, and Guilbert (1996). Solubility is defined as the content of dry matter solubilized after $24 \mathrm{~h}$ immersion in water. The initial dry matter content of each film was determined by drying to constant weight in an oven at $105^{\circ} \mathrm{C}$. Film disks ( $2 \mathrm{~cm}$ diameter) were cut, weighed $\left(M_{i}\right)$, and immersed in $50 \mathrm{ml}$ of water. After $24 \mathrm{~h}$ of immersion at $20{ }^{\circ} \mathrm{C}$ with agitation $(60 \mathrm{rpm})$, the samples were taken out and dried to constant weight $\left(M_{f}\right)$ in an oven at $105^{\circ} \mathrm{C}$, to determine the weight of dry matter that was not solubilized in water. The solubility of each film was then determined as follows: 

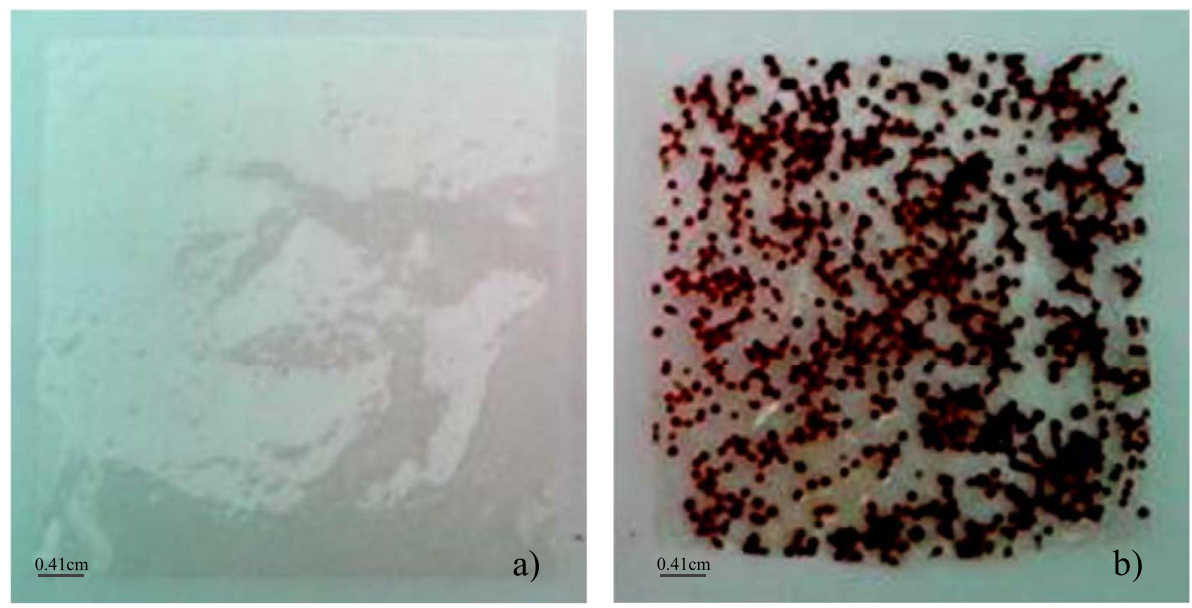

Fig. 2. a) Chitosan control film (CCF) and b) chitosan film with grape seed extract and carvacrol microcapsules (CMF).
Solubility in water $(\%)=\frac{\left(M_{i}-M_{f}\right)}{M_{i}} \times 100$

Here, $M_{i}$ is the initial mass and $M_{f}$ is the final mass of the sample. Three replicates were obtained for each sample.

\subsubsection{Moisture content}

About $50 \mathrm{mg}$ of film were dried at $105{ }^{\circ} \mathrm{C}$ during $24 \mathrm{~h}$ (until the equilibrium weight was attained). The weight loss of the sample was determined, and moisture content was calculated using the following equation:

Moisture content $=\frac{\left(M_{i}-M_{f}\right)}{M_{i}} \times 100$

Here $M_{i}$ and $M_{f}$ are the masses of the initial and dried samples, respectively. Three replicates were obtained for each sample.

\subsubsection{Color}

The color of the films was determined with a Minolta colorimeter (CR 400; Minolta, Osaka, Japan). A white color plate was used as a standard for calibration and as the background for color measurements of the films. $L, a, b$ values of each film were evaluated by reflectance measurements (Rao, Kanatt, Chawla, \& Sharmam, 2010). The measurements were repeated five times for each film. The opacity of the films was determined as the relationship between the opacity of each sample on the black standard $\left(Y_{b}\right)$ and the opacity of each sample on the white standard $\left(Y_{w}\right)$ (Cerqueira et al., 2009a).

\subsubsection{Fourier-transform infrared (FTIR) spectroscopy}

The infrared spectra of the films were determined with a Fouriertransform infrared spectrometer (FTIR; Perkin Elmer 16 PC spectrometer, Boston, USA), based on the method reported by Rubilar, Cruz, Silva et al. (2013), using the attenuated total reflectance mode. Each spectrum results from 16 scans at $4 \mathrm{~cm}^{-1}$ resolution in the spectral range from 650 to $4000 \mathrm{~cm}^{-1}$. All readings were performed at room temperature $\left(20^{\circ} \mathrm{C}\right)$. FTIR spectroscopy was used as a tool to investigate the interactions between chitosan and grape seed polyphenols and carvacrol by measuring the absorbance in the $650-4000 \mathrm{~cm}^{-1}$ wavenumber range at $4 \mathrm{~cm}^{-1}$ resolution. In the case of overlapping peaks, deconvolution was performed to calculate the contribution of the individual peaks using Peakfit software version 4.12 (SYSTAT Software Inc., Richmond, CA, USA). Deconvolution was used to estimate the peak area related to the specific vibration. The film spectra were deconvoluted with a smoothing filter of $15 \%$. Each spectrum was baselinecorrected and the absorbance normalized between 0 and 1 .

\subsubsection{Water vapor permeability (WVP)}

This parameter was determined gravimetrically based on the method ASTM E96-92 (1990), and following Cerqueira, Lima, Teixeira, Moreira, and Vicente (2009b). The film was sealed on the top of a permeation cell containing distilled water (100\% RH; 2337 Pa vapor pressure at $\left.20{ }^{\circ} \mathrm{C}\right)$, placed in a desiccator at $20{ }^{\circ} \mathrm{C}$ and $0 \% \mathrm{RH}(0 \mathrm{~Pa}$ water vapor pressure) containing silica. The cells were weighed each $2 \mathrm{~h}$ for $10 \mathrm{~h}$. Steady-state and uniform water pressure conditions were achieved by maintaining the air circulation constant outside the test cell by using a miniature fan inside the desiccator (McHugh, AvenaBustillos, \& Krochta, 1993). The WVP was estimated using regression analysis from Eq. (3) adapted from Sobral, Menegalli, Hubinger, and Roques (2001):

$\mathrm{WVP}=\frac{w x}{t A \Delta P}$

Here, $A$ is the permeation area $\left(0.005524 \mathrm{~m}^{2}\right), \Delta P$ is the difference of partial vapor pressure of the atmosphere $\left(2337 \mathrm{~Pa}\right.$ at $\left.20{ }^{\circ} \mathrm{C}\right), x$ is the average thickness of the films and the term $w / t$ was calculated by linear regression using the data points for the weight gain vs. time, within the constant rate interval. The measurements were repeated ten times for each film.

\subsubsection{Oxygen and carbon dioxide permeabilities $\left(\mathrm{O}_{2} \mathrm{P}\right.$ and $\left.\mathrm{CO}_{2} \mathrm{P}\right)$}

$\mathrm{O}_{2} \mathrm{P}$ and $\mathrm{CO}_{2} \mathrm{P}$ were determined based on the method ASTM D398502 (2002) and described by Cerqueira et al. (2009b). $\mathrm{O}_{2}$ and $\mathrm{CO}_{2}$ concentrations were determined by gas chromatography (Chrompack 9001, Middleburg, Netherlands) with a Porapak Q column $0.149-0.177 \mathrm{~mm}, 2 \mathrm{~m} \times 0.3175 \mathrm{~cm} \times 2 \mathrm{~mm}$ stainless steel to separate the $\mathrm{CO}_{2}$ and with a molecular sieve $5 \mathrm{~A}$ column $0.149-0.177 \mathrm{~mm}$, $1 \mathrm{~m} \times 0.3175 \mathrm{~cm} \times 2 \mathrm{~mm}$ to separate the $\mathrm{O}_{2}$, followed by a thermal conductivity detector (TCD) at $110{ }^{\circ} \mathrm{C}$. Helium at $23 \mathrm{ml} \mathrm{min}^{-1}$ was used as carrier gas. A mixture containing the following proportion of $\mathrm{CO}_{2}, \mathrm{O}_{2}$ and $\mathrm{N}_{2}(0.1: 0.2: 0.7)$ was used as the standard for calibration. Three replicates were obtained for each sample, in each case $\left(\mathrm{O}_{2} \mathrm{P}\right.$ and $\left.\mathrm{CO}_{2} \mathrm{P}\right)$. Three measurements were taken for each replication.

\subsubsection{Optical microscopy}

Chitosan microcapsules with carvacrol and grape seed extract were observed using a microscope (Motic BA 200, Motic, Xiamen, China) with a camera (Moticam 3.0 MP) and the Motic Images Plus 2.0 software.

\subsection{Refrigerated salmon shelf-life study}

\subsubsection{Sample preparation}

Atlantic salmon (Salmo salar) skinless and boneless fillets were purchased at the local market in Faro, Portugal. The samples were cut approximately into $4 \times 4 \times 1 \mathrm{~cm}^{3}$ chunks. The samples were divided into three groups: Group 1 - control samples (CS), Group 2 - control 
Table 1

Physico-chemical properties of the chitosan film with microcapsules and chitosan control film. All parameters were analyzed in triplicate.

\begin{tabular}{lll}
\hline & $\begin{array}{l}\text { Film with microcapsules } \\
\text { (CMF) }\end{array}$ & Control Film (CCF) \\
& $0.41 \pm 0.04$ & $0.04 \pm 0.01$ \\
Thickness (mm) & $17 \pm 1$ & $34 \pm 4$ \\
Water solubility (\%) & $13 \pm 1$ & $8 \pm 2$ \\
Moisture content $(\mathrm{g}$ & & \\
$\quad$ water/100 g film) & & $95 \pm 3$ \\
Color & $66 \pm 5$ & $-0.5 \pm 0.1$ \\
$L \quad$ & $11 \pm 3 \pm 3$ & $4.8 \pm 0.2$ \\
$a$ & $20 \pm 1$ & $11 \pm 1$ \\
$b$ & $(4.4 \pm 0.4) \times 10^{-10}$ & $(4.4 \pm 0.4) \times 10^{-11}$ \\
Opacity $(\%)$ & $(1.3 \pm 0.3) \times 10^{-12}$ & $(10 \pm 1) \times 10^{-15}$ \\
WVP $\left(\mathrm{gPa}^{-1} \mathrm{~s}^{-1} \mathrm{~m}^{-1}\right)$ & $(1.3 \pm 0.3) \times 10^{-12}$ & $(5 \pm 2) \times 10^{-15}$ \\
$\mathrm{O}_{2} \mathrm{P}\left(\mathrm{gPa}^{-1} \mathrm{~s}^{-1} \mathrm{~m}^{-1}\right)$ & & \\
$\mathrm{CO}_{2} \mathrm{P}\left(\mathrm{gPa}^{-1} \mathrm{~s}^{-1} \mathrm{~m}^{-1}\right)$ & & \\
\hline
\end{tabular}

chitosan film (CCF) and Group 3 - chitosan film with microcapsules of grape seed extract and carvacrol (CMF). The films were placed on the upper surface of the salmon chunks.

\subsubsection{Storage}

Each sample group was placed in polystyrene trays $(22.5 \times 13.8 \times 3.8 \mathrm{~cm})$ and wrapped with polyethylene film. The samples were stored during 14 days in a refrigerated chamber (Aralab, Fitoclima ClimaPlus 400, São Domingos de Rana, Portugal) at $5{ }^{\circ} \mathrm{C}$ and $65 \%$ relative humidity.

\subsubsection{Physico-chemical parameters}

2.3.3.1. $\mathrm{pH}$. The $\mathrm{pH}$ determination was performed using a $\mathrm{pH}$ meter (Crison, micro $\mathrm{pH}$ 2001, Barcelona, Spain) equipped with a $\mathrm{pH}$ electrode (Crison, 52 31). Six measurements were performed for each sample.

2.3.3.2. Total volatile basic nitrogen (TVB-N). The TVB-N values for all salmon samples were determined by the Conway method, using NP 2930:2009 standard (IPQ, 2009). The results were expressed in mg of nitrogen per $100 \mathrm{~g}$ of sample.

2.3.3.3. Moisture content. The determination of moisture was performed with an infrared balance (Mettler LP16M and PM100, Zurich, Switzerland). Four grams of salmon were dried at $160{ }^{\circ} \mathrm{C}$ and measured for each sample.

2.3.3.4. Color. The color of the salmon samples was measured using a colorimeter (Dr. Lange, Spectro-color, Düsseldorf, Germany) in the Hunter Lab scale, D65 illuminant and $10^{\circ}$ observer. Three measurements were run per salmon sample.

2.3.3.5. Texture. The texture of the samples was measured using a texturometer (Brookfield, LFRA Texture Analyzer 1500, Harlow, UK) with a stainless steel probe $4 \mathrm{~mm}$ in diameter (TA34), test speed of $0.5 \mathrm{~mm} / \mathrm{s}$, target distance of $5 \mathrm{~mm}$ and the TextureProLite v1.1 software. Texture profile analysis (TPA) was performed on all of the samples and the parameter values for hardness, cohesiveness, adhesiveness and springiness were obtained. Three measurements were run per salmon sample.

\subsubsection{Microbiological analyses}

Samples were analyzed for mesophilic and psychrophilic bacteria using plate count agar (PCA, Liofilchem) and Pseudomonas spp using cetrimide agar (Scharlau). Each sample (10 g) was diluted 1:10 in sterile distilled water and the mixture was homogenized for $2 \mathrm{~min}$ in a stomacher (model 400, Seward, UK). After serial dilutions in PBS solution (Merck), aliquots of $1 \mathrm{ml}$ were inoculated in PCA and cetrimide agar, and the plates were incubated at $37 \pm 2{ }^{\circ} \mathrm{C}$ for $48 \mathrm{~h}, 7 \pm 2{ }^{\circ} \mathrm{C}$ for 7-10 days and $44 \pm 2{ }^{\circ} \mathrm{C}$ for $48 \mathrm{~h}$ to determine mesophilic bacteria, psychrophilic bacteria and Pseudomonas spp., respectively. All analyses were run in duplicate.

\subsection{Statistical analysis}

The experimental data were processed with SPSS software Statistical Product and Service Solutions version 22. An analysis of variance (ANOVA) was performed to detect significant differences among the samples. The significance level was set at 0.05 . The least significant difference (LSD) was used as a post-hoc test to detect which pair/pairs of samples presented significant differences.

\section{Results and discussion}

\subsection{Film characterization}

\subsubsection{Color and thickness}

The physico-chemical properties of each of the films are presented in Table 1 . As regards color, the CMF presented a lower $L$ value, indicating that these films were darker than CCF. Positive values were obtained for $a$ and $b$, which indicates that these films were in the zone of red and yellow. The change in the luminosity of the films was due to the incorporation of the active agents carvacrol and GSE, as verified in the study by Rubilar, Cruz, Silva et al. (2013). CMF showed positive $a$ values while CCF displayed negative $a$ values. This indicates that color changed to a reddish tone due to the incorporation of GSE (also of reddish coloration). Both CCF and CMF showed positive $b$ values, though higher for CMF as a result of its more yellowish appearance, which may also be due to the incorporation of GSE. The presence of microcapsules also changed the opacity of the film, with the CMF around the double of the opacity of the CCF.

CCF showed similar thickness values, with the results also similar to those of several other studies, such as the one reported by Imran, Klouj, Revol-Junelles, and Desobry (2014) on the controlled release of nisin, sodium caseinate, poly-lactic acid and chitosan for active packaging applications. The CMF was about 10 times thicker than the CCF, due to the incorporation of the microcapsules. The increase in chitosan film thickness was also verified in the study by Ojagh, Rezaei, Razavi, and Hosseini (2010), as cinnamon essential oil was incorporated in increasing amounts into the films, and in the study by Martins, Cerqueira, and Vicente (2012) on the influence of the addition of $\beta$-tocopherol on the physico-mechanical properties of chitosan films.

\subsubsection{Moisture content and water solubility}

In what concerns the moisture content and water solubility, the CMF showed lower water solubility but presented higher value of moisture content. These results are similar to those obtained in the study reported by Rubilar, Cruz, Silva et al. (2013). The increase of the moisture content of the CMF may be due to GSE, whose main components have hydrophilic groups in their structure (Yamakoshi, Kataoka, Koga, \& Ariga, 1999). The higher solubility of CCF can be attributed to the ability of water molecules to bind to the plasticizer (glycerol) and functional groups of chitosan, as described in the study by Ojagh et al. (2010) on the development and evaluation of chitosan films incorporating cinnamon essential oil. The lower solubility of the CMF may be due to the presence of carvacrol and its hydrophobic nature, preventing interaction with the water molecules as described in Rubilar, Cruz, Silva et al. (2013). The solubility of the films in water can provide indications about the film behavior in aqueous environments, being a measure of its water resistance, and therefore related to the hydrophilicity of the materials. This is also an important factor that determines the biodegradability of the films when used as packaging materials. The resistance of the films to water, as determined by their solubility, is critical for their potential applications. High solubility in 


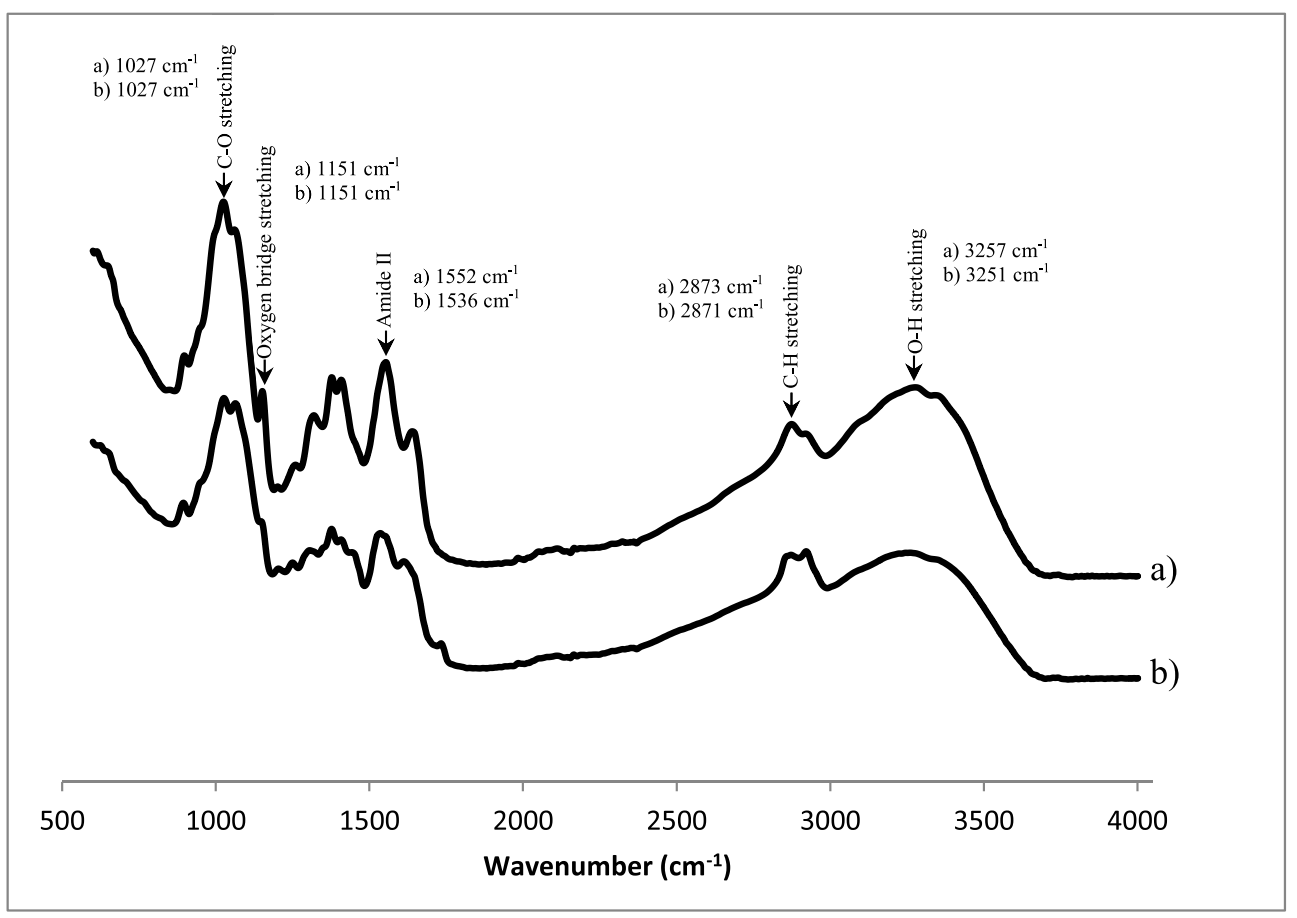

Fig. 3. Fourier transform infrared (FTIR) spectra of the studied films. a) chitosan control film (CCF); b) chitosan film with grape seed extract and carvacrol microcapsules (CMF). water is sometimes desired when the film will be consumed simultaneously with the food. However, in other technological applications, low water solubility is required, as is the case with highly moist food packages (Rubilar, Cruz, Silva et al., 2013).

\subsubsection{Water vapor (WVP), $\mathrm{O}_{2}\left(\mathrm{O}_{2} \mathrm{P}\right)$ and $\mathrm{CO}_{2}\left(\mathrm{CO}_{2} \mathrm{P}\right)$ permeabilities}

$\mathrm{CMF}$ presented higher values of the tested permeabilities compared with the CCF (Table 1). The WVP required for an active film depends on the food to be packaged, and generally must be low to avoid or decrease the moisture transfer between the surrounding atmosphere and the food (Bourdon et al., 2011; Li et al., 2014). The transfer of water vapor generally occurs through the hydrophilic part of the film and depends on the ratio of the hydrophobic and hydrophilic constituents of the film (Bourdon et al., 2011; Jouki, Mortazavi, Yazdi, \& Koocheki, 2014; Wu et al., 2014). There are several factors that can affect the WVP, such as film thickness and crystallinity (Jouki et al., 2014). Thus, the transfer of water vapor through a semicrystalline polymer occurs mainly in the amorphous phase, because the crystalline phase creates a much greater barrier to the passage of the water molecules. Therefore, as the percentage of crystallinity of a polymer increases, the gas permeability decreases (Bourdon et al., 2011; Rubilar, Cruz, Silva et al., 2013). Due to the release of GSE, which is hydrophilic, the water molecules are easier bonded by hydrogen bonds, as the additive has many hydroxyl groups, turning the polymer more permeable and allowing the absorption of water molecules by the film (Rubilar, Cruz, Silva et al., 2013). In addition, the presence of GSE may lead to less crystalline films, also leading to increased WVP (Rubilar, Cruz, Silva et al., 2013), as observed in this study where the WVP of the CMF were higher in relation to CCF. The study by Rubilar, Cruz, Silva et al. (2013) also demonstrated that lower concentrations of GSE and higher concentrations of carvacrol led to the reduction of WVP due to the hydrophobic nature of carvacrol, which affects the hydrophilic and hydrophobic balance of the film. The developed films presented similar WVP to fish gelatin-chitosan $(1.5 \mathrm{~g} / 100 \mathrm{ml})$ films incorporated with $1.2 \mathrm{~g}$ oregano oil/100 ml (2.11 \pm 0.05$) \times 10^{-10} \mathrm{gPa}^{-1} \mathrm{~s}^{-1} \mathrm{~m}^{-1}$ (Hosseini et al., 2015a). In another study, chitosan $(1 \mathrm{~g} / 100 \mathrm{ml})$ nanocapsules formed by ionic gelation with TPP $(0.4 \mathrm{~g} / 100 \mathrm{ml})$ were embedded into a film with fish gelatin $(4 \mathrm{~g} / 100 \mathrm{ml})$ and the results similar to those of the present study were obtained. Namely, the control film showed a WVP of
$(3.9 \pm 0.2) \times 10^{-10} \mathrm{gPa}^{-1} \mathrm{~s}^{-1} \mathrm{~m}^{-1}$ while the film with $8 \mathrm{~g}$ nanocapsules $/ 100 \mathrm{~g}$ of fish gelatin presented a value of $(2.5 \pm 0.4) \times 10^{-10} \mathrm{gPa}^{-1} \mathrm{~s}^{-1} \mathrm{~m}^{-1}$ (Hosseini, Rezaei, Zandi, \& Farahmandghavi, 2015b).

$\mathrm{CMF}$ had $\mathrm{O}_{2} \mathrm{P}=(1.3 \pm 0.3) \times 10^{-12} \mathrm{gPa}^{-1} \mathrm{~s}^{-1} \mathrm{~m}^{-1}$ while the CCF showed a lower value $\mathrm{O}_{2} \mathrm{P}=(10 \pm 1) \times 10^{-15} \mathrm{gPa}^{-1} \mathrm{~s}^{-1} \mathrm{~m}^{-1}$. The $\mathrm{O}_{2} \mathrm{P}$ of the food packaging materials is of great importance for food preservation, since oxygen is the factor that can cause oxidation and initiate various deterioration reactions. By nature, polysaccharide films provide a good barrier to oxygen, since their hydrogen network is well organized (Bourdon et al., 2011; Jouki et al., 2014; Rubilar, Cruz, Silva et al., 2013). $\mathrm{O}_{2} \mathrm{P}$ depends on the films' crystallinity, the higher the crystallinity the lower the oxygen transmission (Rubilar, Cruz, Silva et al., 2013). According to Rubilar, Cruz, Silva et al. (2013) the films' $\mathrm{O}_{2} \mathrm{P}$ is increased by the incorporation of high GSE concentrations. Nevertheless, $\mathrm{O}_{2} \mathrm{P}=(6 \pm 1) \times 10^{-13} \mathrm{gPa}^{-1} \mathrm{~s}^{-1} \mathrm{~m}^{-1}$ was obtained in chitosan films with the incorporation of natural extracts at the same concentrations as used in the microcapsules of the present study.

As regards $\mathrm{CO}_{2} \mathrm{P}$, the $\mathrm{CMF}$ permeability was higher $\mathrm{CO}_{2} \mathrm{P}=$ $(1.3 \pm 0.3) \times 10^{-12} \mathrm{gPa}^{-1} \mathrm{~s}^{-1} \mathrm{~m}^{-1}$, than that of $\mathrm{CCF}, \mathrm{CO}_{2} \mathrm{P}=$ $(5 \pm 2) \times 10^{-15} \mathrm{gPa}^{-1} \mathrm{~s}^{-1} \mathrm{~m}^{-1}$. Generally, the gas permeability is dependent on the film crystallinity, with the increased crystallinity causing a reduced $\mathrm{CO}_{2} \mathrm{P}$ (Bourdon et al., 2011). In the study by Rubilar, Cruz, Silva et al. (2013) chitosan films incorporating GSE and carvacrol were developed, having lower $\mathrm{CO}_{2} \mathrm{P}=(3.7 \pm 0.4) \times 10^{-13}$ $\mathrm{gPa}^{-1} \mathrm{~s}^{-1} \mathrm{~m}^{-1}$ as compared to CMF.

\subsubsection{Fourier transform infrared spectrum (FTIR)}

Fourier transform infrared spectra of all of the films are shown in Fig. 3. FTIR was used to evaluate possible chemical interactions between chitosan and the bioactive compounds introduced as microcapsules. The peaks obtained in the FTIR showed the same behavior in CCF and CMF, however there was an artifact flattening of the CMF FTIR due to existence of the microcapsules. As the film is quite heterogeneous the peak amplitudes correspond to the mean value, so the peak amplitudes differ slightly between the two films studied (CCF and CMF), as described by several authors, depending on the amount of extracts added and the amplitudes of the spectrum (Hosseini et al., 2015a; Rubilar, Cruz, Silva et al., 2013). At $1027 \mathrm{~cm}^{-1}$ a C-O stretching 
for CCF and CMF was observed, this peak corresponds to the hydroxyl group $(\mathrm{OH})$ of the saccharine structures (Arancibia, Alemán, LópezCaballero, Gómez-Guillén, \& Montero, 2015; Bonilla, Fortunati, Atarés, Chiralt, \& Kenny, 2014; Silva-Weiss, Bifani, Ihl, Sobral, \& GómezGuillén, 2013), especially glycerol used as plasticizer (Hosseini et al., 2015a). The oxygen bridge elongation mode at $1151 \mathrm{~cm}^{-1}$ was observed in both films (CCF and CMF). This mode is also typical for saccharin structures (Arancibia et al., 2015; Bonilla et al., 2014; Hosseini et al., 2015a), indicating that the length of the glycosidic chain was slightly modified with the addition of microcapsules into the film (Silva-Weiss et al., 2013). Some of the peaks were transferred to lower wavenumbers with the incorporation of the extracts, for example, the $1552 \mathrm{~cm}^{-1}$ and $1536 \mathrm{~cm}^{-1}$ peaks for the CCF and CMF, respectively, which correspond to the Amide II group (Bonilla et al., 2014; Hosseini et al., 2015a; Rubilar, Cruz, Silva et al., 2013). A peak at $1712 \mathrm{~cm}^{-1}$ was also observed for the CMF. This peak, according to Silva-Weiss et al. (2013), is related to the presence of quercetin in the microcapsules of the film, as well as the ester-bond between chitosan and the polyphenol extracts. A C-H group stretching at $2873 \mathrm{~cm}^{-1}$ and $2871 \mathrm{~cm}^{-1}$ was also observed suggesting that hydrogen bonds may occur between the chitosan carbon groups and the hydroxyl groups of the polyphenols present in the extracts (Silva-Weiss et al., 2013). Finally, there was a stretching of the hydroxyl group (O-H) at $3257 \mathrm{~cm}^{-1}$ and $3251 \mathrm{~cm}^{-1}$ for CCF and CMF, respectively, representing intermolecular bonds of chitosan molecules, mainly polymeric hydrogen bonds (Arancibia et al., 2015; Hosseini et al., 2015a; Silva-Weiss et al., 2013; Vodnar, 2012). The peak amplitude decreased in CMF due to presence of polyphenols, which form intramolecular and intermolecular hydrogen bonds (Li et al., 2014).

Li et al. (2014) studied a gelatin film $(3 \mathrm{~g} / 100 \mathrm{ml})$ with incorporated GSE, confirming the results presented in this work. The addition of the extract was verified by the presence of $\mathrm{C}-\mathrm{O}$ and $\mathrm{C}-\mathrm{C}$ bonds between $1000 \mathrm{~cm}^{-1}$ and $1300 \mathrm{~cm}^{-1}$, respectively. Also, $\mathrm{C}=\mathrm{O}$ and $\mathrm{N}-\mathrm{H}$ stretching representing Amide II between $1500 \mathrm{~cm}^{-1}$ and $1675 \mathrm{~cm}^{-1}$, for gelatin film and gelatin film with incorporated GSE, respectively. In another study (Hosseini et al., 2015b), chitosan film (1.5 g/100 ml) and another with oregano oil $(1.2 \mathrm{~g} / 100 \mathrm{ml})$ showed spectra similar to the ones obtained in this study. The films showed a peak at $3327 \mathrm{~cm}^{-1}$, which corresponds to a stretching oscillation of the hydroxyl $(\mathrm{OH})$ group, another one at $1546 \mathrm{~cm}^{-1}$ of the amide group II, and the peaks located between 1042 and $1045 \mathrm{~cm}^{-1}$ corresponding to the hydroxyl group.

\subsection{Refrigerated salmon shelf-life study}

\subsubsection{Physico-chemical parameters}

Table 2 presents the physico-chemical parameters of fresh salmon. Luminosity of the salmon samples with CS, CCF and CMF films presented the same behavior (Fig. 4). From day 0 to day 1 , a significant increase $(p<0.05)$ from 42 to values between 45 and 50 was observed, meaning that the salmon samples became lighter. Throughout the remaining days, from day 1 to day 14, the luminosity values of the samples were approximately constant. However, the samples in CMF throughout the storage showed luminosity values closer to those of the fresh salmon, as compared to CS and CCF samples. Moreover, the CMF samples at the end of the storage time were not as light and milky as the CS and CCF samples (Fig. 5). This fact may be due to the presence of polyphenols, in particular, to the proanthocyanidins present in grape seed extract, which when transferred from the film to the sample, maintained the samples slightly darker, confirming that chitosan alone does not have a positive effect on the samples (Rubilar, Cruz, Khmelinskii et al., 2013). In a study where the red snapper samples (Pagrus pagrus) were coated with a solution of chitosan $(2 \mathrm{~g} / 100 \mathrm{ml})$ and another solution of chitosan $(2 \mathrm{~g} / 100 \mathrm{ml})$ with oregano oil $(0.1 \mathrm{~g} /$ $100 \mathrm{ml}$ ) and stored at $4{ }^{\circ} \mathrm{C}$ for 20 days, despite slight variations in the two treatments, the addition of oregano oil did not significantly affect
Table 2

Physico-chemical and microbiological parameters of fresh salmon for shelf-life study (analyzed in triplicate and duplicate, respectively).

$\begin{array}{ll}\text { Physico-chemical } & \\ \mathrm{pH} & 6.2 \pm 0.1 \\ \text { TVB-N (mg N/100 g) } & 12 \pm 3 \\ \text { Moisture content (g water/100 g fish) } & 60 \pm 3 \\ \text { Color } & \\ L & 42 \pm 2 \\ a & 15 \pm 2 \\ b & 14 \pm 2 \\ \text { Texture } & \\ \text { Hardness (g) } & 123 \pm 26 \\ \text { Cohesiveness } & 0.19 \pm 0.02 \\ \text { Adhesiveness (gs) } & -61 \pm 27 \\ \text { Springiness (mm) } & 1.9 \pm 0.4 \\ \text { Microbiological } & \\ \text { Mesophilic bacteria (log(CFU/g) } & 3.9 \pm 0.3 \\ \text { Psychrophilic bacteria (log(CFU/g)) } & 4.9 \pm 0.5 \\ \text { Pseudomonas spp. (log(CFU/g)) } & 0.8 \pm 0.5\end{array}$
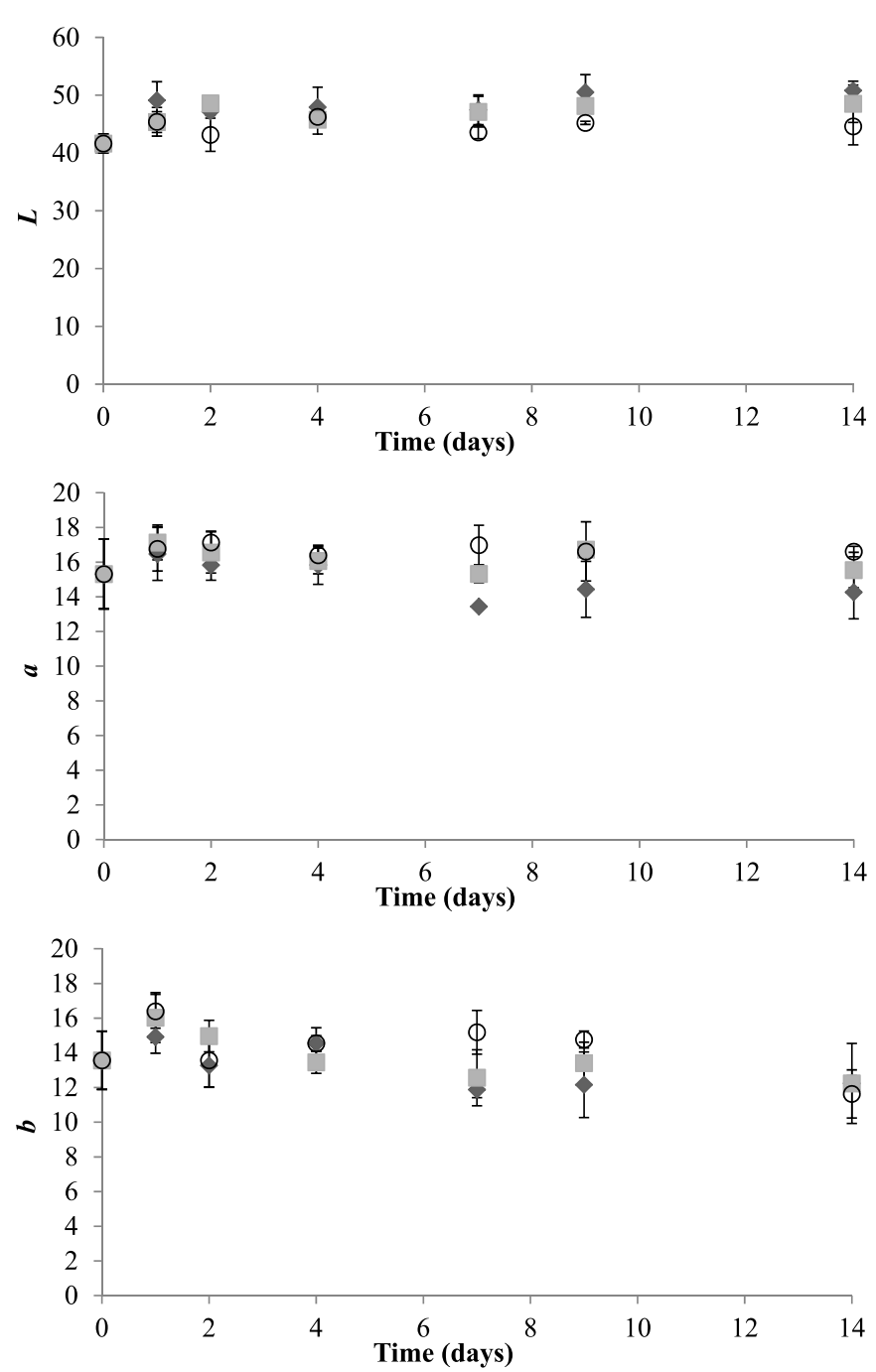

Fig. 4. Lab colour values for salmon samples during 14 days of storage at $5{ }^{\circ} \mathrm{C}$. $\diamond$ control sample (CS), $\square$ chitosan control film (CCF) and $\mathrm{O}$ chitosan film with grape seed extract and carvacrol microcapsules (CMF).

( $p>0.05$ ) the luminosity of the samples (Vatavali, Karakosta, Nathanailides, Georgantelis, \& Kontominas, 2013). In a work reported by Nicorescu, Nguyen, Chevalier, and Orange (2014), the $L$ values of salmon are in agreement with the results obtained in this work. At day 0 


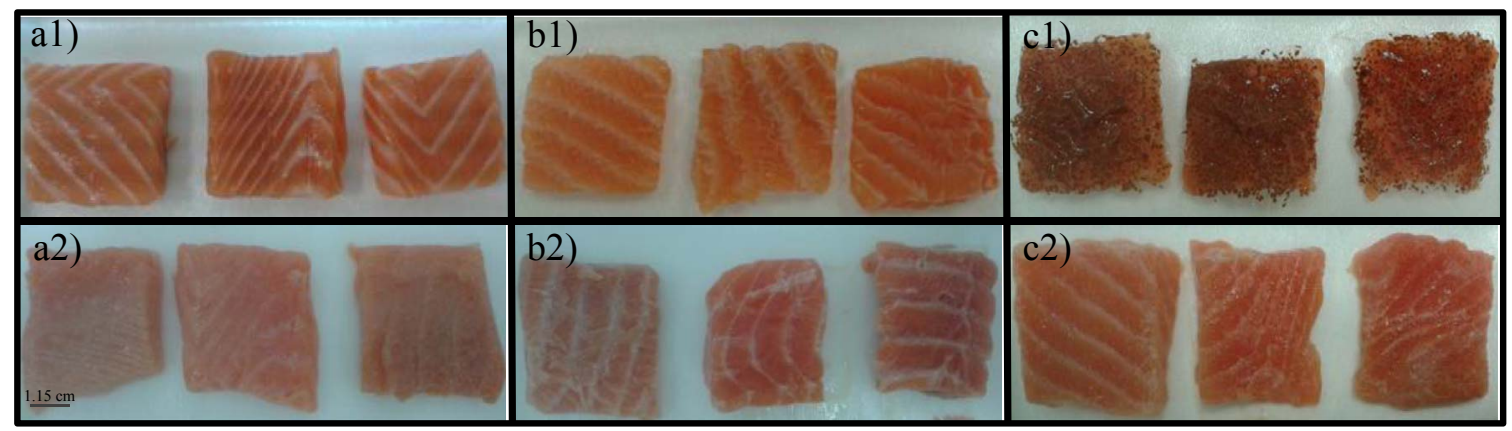

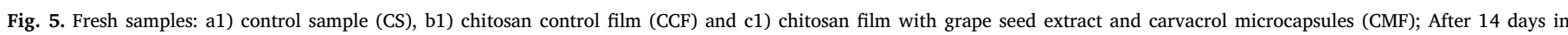
refrigerated storage: a2) CS, b2) CCF and c2) CMF.

the samples showed a value of approximately 46, with $47 \pm 4$ and of $47 \pm 2$ on day 7 stored at $4{ }^{\circ} \mathrm{C}$, for the control and samples irradiated with $30 \mathrm{~J} / \mathrm{cm}^{2}$, respectively.

Regarding the $a$ parameter, its values were approximately constant for all of the stored samples from day 0 to day 14 of storage. The reddish color of salmon was maintained throughout the storage; however, the $a$ values for the salmon samples with CMF were slightly higher compared to CS and CCF samples, although not significantly (Fig. 4). These results are also corroborated with the results showed in Fig. 5, where the CMF presented a better preservation of the characteristic red color of salmon, which may be attributed to polyphenols, especially proanthocyanidins present in grape seed extract, as previously mentioned. According to Vatavali et al. (2013) a coating with chitosan (2 g/ $100 \mathrm{ml})$ and oregano oil $(0.1 \mathrm{~g} / 100 \mathrm{ml})$ also protected the red color of the red snapper (Pagrus pagrus) between the 6th and the 20th days of storage at $4{ }^{\circ} \mathrm{C}$.

The salmon samples presented almost constant values for the $b$ parameter between the 11th and the 17th day (Fig. 4). All of the samples presented some variability throughout the storage period but no considerable changes were detected, besides the decrease of the salmon control sample at the 7th day of storage. These values are in accordance with the study reported by Vatavali et al. (2013) in which the values of $b$ in red snapper (Pagrus pagrus) varied between 8 and 12, without significant differences between the control treatments, coating with chitosan $(2 \mathrm{~g} / 100 \mathrm{ml})$ and chitosan $(2 \mathrm{~g} / 100 \mathrm{ml})$ with oregano oil $(0.1 \mathrm{~g} / 100 \mathrm{ml})$.

In what concerns $\mathrm{pH}$ (Fig. 6a), a significant increase in the control samples $(p<0.05)$ was observed between the 4 th and the 7 th days of storage with values from $6 \pm 1$ to $6.6 \pm 0.1$. The control samples showed a maximum value of $7.1 \pm 0.1$ at the 14 th day of storage. These results confirmed that the control samples were degrading at a faster rate during the storage time. The higher $\mathrm{pH}$ values may be related to the fast deterioration of the product with the production of alkaline compounds due the autolysis of nitrogen compounds such as ammonia, trimethylamine and other biogenic amines, and further, due to deterioration by bacterial proliferation (Li, Li et al., 2013; Qiu, Chen, Liu, \& Yang, 2014; Souza et al., 2010; Vatavali et al., 2013).

In samples packed with $\mathrm{CCF}$ a $\mathrm{pH}$ increase from $6.3 \pm 0.1$ to $6.4 \pm 0.1$ from the 4 th to the 7 th day of storage was observed. Thus, these samples were degrading more slowly than the control samples. However, in the samples packed with CMF a more pronounced increase in $\mathrm{pH}$ was only observed between days 9 and 14 of storage, showing values from $6.3 \pm 0.1$ to $6.7 \pm 0.1$. Thus, the CMF maintained the $\mathrm{pH}$ lower for longer time, delaying the degradation of the samples over at least 9 days, in what concerns the evaluated parameter. Similar results were reported for other fish species coated with chitosan. In a study with red snapper stored at $4{ }^{\circ} \mathrm{C}$ the initial $\mathrm{pH}$ was 6.6 . The $\mathrm{pH}$ of the samples coated with chitosan $(2 \mathrm{~g} / 100 \mathrm{ml})$ with or without oregano oil $(0.1 \mathrm{~g} / 100 \mathrm{ml})$ increased throughout storage (6.7 at 13 days storage), but was lower than that of the control samples (6.9 at 13th day of
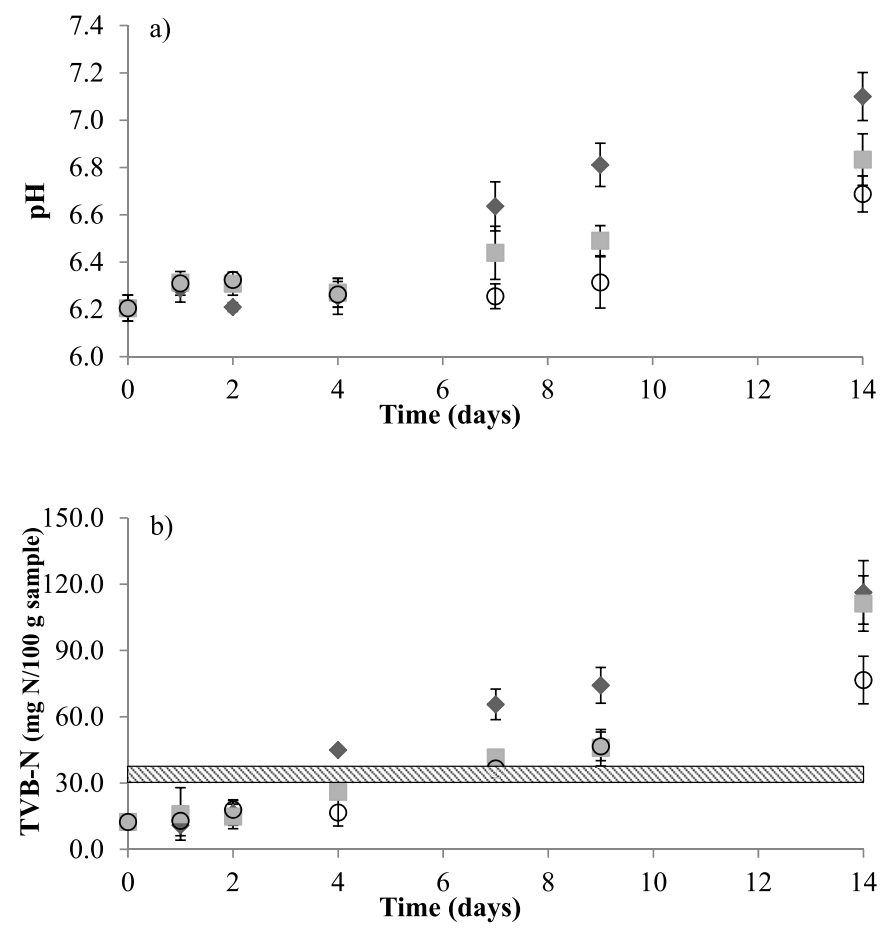

Fig. 6. a) $\mathrm{pH}$ and b) TVB-N values for salmon samples during 14 days of storage at $5{ }^{\circ} \mathrm{C}$. $\diamond$ control sample (CS), $\square$ chitosan control film (CCF) and $\bigcirc$ chitosan film with grape seed extract and carvacrol microcapsules (CMF). The horizontal area with pattern represents the rejection limit for fish flesh, which is 30-35 mg TVB-N/100 g, (CE) N. ${ }^{\circ} 2074 / 2005$.

storage, $p<0.05$ ). The lower $\mathrm{pH}$ values are related to the antimicrobial action of the natural agents present in the CMF, which inhibit the bacteria that cause protein degradation and the production of basic compounds responsible for the $\mathrm{pH}$ increase (Vatavali et al., 2013).

In a study with redfish (Sciaenops ocellatus) the results were also in accordance with those presently reported. The $\mathrm{pH}$ of the control sample was higher than the $\mathrm{pH}$ of the samples coated with chitosan $(1.5 \mathrm{~g} /$ $100 \mathrm{ml})$ and grape seed extract $(0.2 \mathrm{~g} / 100 \mathrm{ml})(p<0.05)$ during storage at $4{ }^{\circ} \mathrm{C}$ (Li, Li et al., 2013).

The results for TVB-N are presented in Fig. 6b. Fresh salmon samples showed initial values of $12 \pm 3 \mathrm{mg} \mathrm{N} / 100 \mathrm{~g}$ of salmon. The TVB-N values increased throughout the storage time for all the studied samples showing on day 14 values of $116 \pm 14,111 \pm 13$ and $77 \pm 11 \mathrm{mg} \mathrm{N} / 100 \mathrm{~g}$ of salmon for the CS, CCF and CMF, respectively. The CMF samples showed lower values than the other studied samples, maintaining the fish with low TVB-N values mainly between the 4th and the 7th days of storage. These differences may be attributed to the antimicrobial activity of chitosan and the extracts present in the microcapsules, contributing to the reduction of the bacterial population or the reduction of the capacity of the bacteria to perform oxidative 
deamination (Souza et al., 2010). The values of TVB-N remained stable during the first two days of storage, however, an increase in the control samples exceeding $35 \mathrm{mg}$ of N/100 $\mathrm{g}$ (established as the limit of the acceptability of salmon by Regulation (EC) No 2074/2005) was observed already on the 4th day.

CCF samples showed a significant increase from the 4th to the 7th days $(p<0.05)$ from $26 \pm 1$ to $42 \pm 3 \mathrm{mg} \mathrm{N} / 100 \mathrm{~g}$ of salmon, exceeding the maximum limit of $35 \mathrm{mg} \mathrm{N} / 100 \mathrm{~g}$ of fish. The salmon samples packed with CMF also showed a significant increase from the 4 th to the 7 th days $(p<0.05)$. However, the value of TVB-N at day 7 (37 $\pm 4 \mathrm{mg} \mathrm{N} / 100 \mathrm{~g}$ of salmon) was still within the maximum limit of $35 \mathrm{mg} \mathrm{N} / 100 \mathrm{~g}$ of fish, indicating lower degradation of salmon stored at $5{ }^{\circ} \mathrm{C}$ with $\mathrm{CMF}$. The antimicrobial activity of CMF may maintain or retard the growth of microorganisms that perform oxidative deamination of non-protein nitrogen compounds (Li, Li et al., 2013).

In a study with red fish fillets (Sciaenops ocellatus) the values of TVB$\mathrm{N}$ also increased progressively $(p<0.05)$. The initial values were around $6 \mathrm{mg} \mathrm{N} / 100 \mathrm{~g}$ and at the 20th day of storage at $4{ }^{\circ} \mathrm{C}, 51$ and $38 \mathrm{mg} \mathrm{N} / 100 \mathrm{~g}$ for the control and chitosan $(1.5 \mathrm{~g} / 100 \mathrm{ml})$ with grape seed extract $(0.2 \mathrm{~g} / 100 \mathrm{ml})$, respectively (Li, Li et al., 2013).

In another study carried out on carp samples (Ctenopharyngodon idellus) the values of TVB-N during 12 days of storage at $4{ }^{\circ} \mathrm{C}$ presented the same behavior as those in the present study. The control samples and those packed with Parafilm showed an increase from $8 \mathrm{mg} \mathrm{N} /$ $100 \mathrm{~g}$ to $55 \mathrm{mg} \mathrm{N} / 100 \mathrm{~g}$, while the samples packed in chitosan with oregano essential oil ( $4 \mathrm{ml}$ oil/100 ml) were significantly lower $(p<0.05$ ), showing $40 \mathrm{mg} \mathrm{N} / 100 \mathrm{~g}$ on the last day of storage. Considering the limit value of $35 \mathrm{mg} \mathrm{N} / 100 \mathrm{~g}$, the shelf-life of samples packed in chitosan with oregano oil $(4 \mathrm{ml}$ oil/100 ml) was extended to 12 days (Wu et al., 2014).

Refrigerated sea bass (Lateolabrax japonicas) showed an increase from $11 \mathrm{mg} \mathrm{N} / 100 \mathrm{~g}$ on day $0-100 \mathrm{mg} \mathrm{N} / 100 \mathrm{~g}$ after 12 days of storage at $4{ }^{\circ} \mathrm{C}$. The maximum limit of $35 \mathrm{mg} \mathrm{N} / 100 \mathrm{~g}$ was exceeded on the 8 th day of storage. However, chitosan coated samples $(1.5 \mathrm{~g} / 100 \mathrm{ml})$ presented at the end of storage (day 12) a value of $61 \mathrm{mg} \mathrm{N} / 100 \mathrm{~g}$ and the ones coated with chitosan $(1.5 \mathrm{~g} / 100 \mathrm{ml})$ and citric acid $(0.5 \mathrm{~g} / 100 \mathrm{ml})$ presented still a lower value of TVB-N (48 mg N/100 g) (Qiu et al., 2014).

Regarding the texture of the samples, no significant differences $(p>0.05)$ were observed for the tested parameters throughout the storage. However, the CMF salmon samples were visibly more cohesive compared to the CS and CCF samples.

Although CS, CCF and CMF samples showed some variation in the moisture content throughout the storage due to drip loss, no significant differences were observed among samples, with the values remaining practically constant between $45 \pm 3 \mathrm{~g}$ water/100 $\mathrm{g}$ of fish and $60 \pm 3 \mathrm{~g}$ water/100 $\mathrm{g}$ of fish. Nevertheless, a pronounced decrease was observed from day 0 to day 1 , indicating a greater loss of water in the samples.

\subsubsection{Microbiological parameters}

Table 2 also presents the microbiological parameters of fresh salmon. Fig. 7 shows the effect of the tested packages on the mesophilic bacteria, psychrophilic bacteria and Pseudomonas spp. growth in the refrigerated salmon. The CS and CCF samples, showed values of $7.2 \pm 0.3 \log (\mathrm{CFU} / \mathrm{g})$ and $7.2 \pm 0.6 \log (\mathrm{CFU} / \mathrm{g})$ for mesophilic bacteria, respectively, on the 4 th day of storage at $5{ }^{\circ} \mathrm{C}$, exceeding the maximum limit of $7 \log (\mathrm{CFU} / \mathrm{g})$. On the other hand, the CMF samples showed a pronounced increase only between the 4th and the 7th days of storage, from $4.8 \pm 0.6$ to $7.1 \pm 0.3 \log (\mathrm{CFU} / \mathrm{g})$. Thus, the $\mathrm{CMF}$ delayed the deterioration of salmon samples due to the active compounds with antimicrobial and antioxidant properties that affect the cellular membranes and retard microbial growth (Rubilar, Cruz, Khmelinskii et al., 2013).

Similar results were found in the study by Wu et al. (2014) carried out in carp (Ctenopharyngodon idellus) stored at $5{ }^{\circ} \mathrm{C}$ and packed with
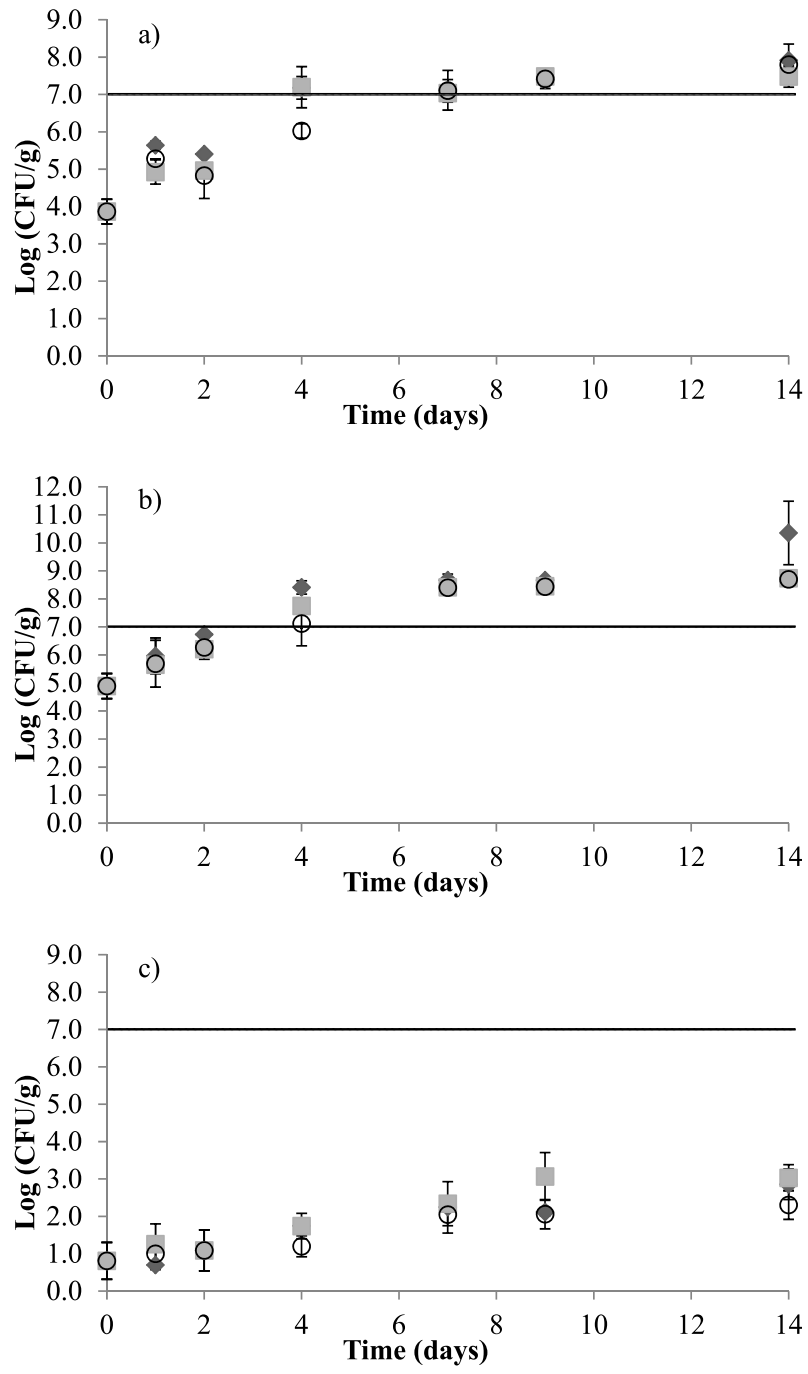

Fig. 7. a) Mesophilic, b) psychrophilic bacteria and c) Pseudomonas spp. values for salmon samples during 14 days of storage at $5{ }^{\circ} \mathrm{C}$. $\diamond$ control sample (CS), $\square$ chitosan control film (CCF) and $\mathrm{O}$ chitosan film with grape seed extract and carvacrol microcapsules (CMF). The horizontal lines represent the maximum limit $(7.0 \log (\mathrm{CFU} / \mathrm{g})$ ) allowed for consumption (Monitoring \& Surveillance Series, 2010; Nowzari et al., 2013; Souza et al., 2010; Vatavali et al., 2013).

chitosan film incorporated with of oregano oil (4 $\mathrm{ml}$ oil/100 ml), which proved to have a good antimicrobial activity. The high microbial growth rate in the present study is due to the composition of the nutrient-rich fish, namely basic nitrogen, which makes it favorable for microbial growth (Nowzari, Shábanpour, \& Ojagh, 2013; Souza et al., 2010).

In what concerns the psychrophilic bacteria, the CS exceeded 7 log $\left(\mathrm{CFU} / \mathrm{g}\right.$ ) at day 4 of storage at $5{ }^{\circ} \mathrm{C}$ with $8.4 \pm 0.2 \log (\mathrm{CFU} / \mathrm{g})$. CCF and CMF samples also reached the limit value at day 4 with $7.8 \pm 0.3$ $\log (\mathrm{CFU} / \mathrm{g})$ and $7.1 \pm 0.8 \log (\mathrm{CFU} / \mathrm{g})$, respectively. Nevertheless, the samples packed with CMF showed higher values of psychrophilic bacteria only at the 7th day of storage with $8.4 \pm 0.1 \log (\mathrm{CFU} / \mathrm{g})$. These bacteria are the main group of microorganisms responsible for the deterioration of fresh fish stored at refrigerated temperatures (Nowzari et al., 2013). This shows that the release of natural agents into salmon samples has a beneficial effect, since it reduced the growth rate of the microorganisms studied.

The action of polyphenolic compounds and phenolic acids with antibacterial and antioxidant activity was significant. These compounds confer an inhibitory effect, primarily against Gram-positive microorganisms. Polyphenols can penetrate the bacterial semipermeable 
membrane and react with cytoplasm or cellular proteins, destabilizing the microbial cells (Corrales et al., 2014).

According to Sallam, (2007), the results for salmon samples (Onchorhynchus nerka) are in agreement with the present work. An initial count of approximately 4 log psychrophilic bacteria (CFU/g) was recorded and at the 15th day of storage at $1{ }^{\circ} \mathrm{C}$ different samples treated with sodium acetate, sodium lactate and sodium citrate presented counts of 7.1, 8.2 and $8.5 \log (\mathrm{CFU} / \mathrm{g})$, respectively, whereas the control salmon samples showed a value of $10.4 \log (\mathrm{CFU} / \mathrm{g})$.

In relation to Pseudomonas spp. no significant differences were observed between day 0 and day $2(p>0.05)$ in all of the studied samples, the values ranged from the minimum of $0.7 \pm 0.0$ to the maximum of $1.1 \pm 0.6 \log (\mathrm{CFU} / \mathrm{g})$. In the control samples an increase from day 4 to day 7 was observed from $1.8 \pm 0.1$ to $2.3 \pm 0.1 \log$ $(\mathrm{CFU} / \mathrm{g})$. In the CCF samples there were significant differences $(p<0.05)$ from day 2 to day 4 from $1.1 \pm 0.6$ to $1.7 \pm 0.3 \log (\mathrm{CFU} /$ g).

In the samples packed with CMF there were no significant differences $(p>0.05)$ from day 0 to day 4 . From the 4th day of storage a significant increase $(p<0.05)$ was observed in Pseudomonas spp. counts, with the salmon samples at the 7th day of storage in a higher degradation state. It was also found that the growth of the microorganisms in CMF was slower compared to CS and CCF samples. Nevertheless, the allowed maximum limit of $7.0 \log (\mathrm{CFU} / \mathrm{g}$ ) was not exceeded in any of the three cases under study.

In general, the microbial tests showed that salmon samples packed in CMF maintained acceptable values of mesophilic bacteria, psychrophilic bacteria and Pseudomonas spp. up to 4-7 days of storage.

\section{Conclusion}

The incorporation of microcapsules with grape seed extract and carvacrol affected the physicochemical properties of the developed films, increasing their thickness, moisture content, $a$ and $b$ color parameters, WVP, $\mathrm{O}_{2} \mathrm{P}$ and $\mathrm{CO}_{2} \mathrm{P}$, when compared with the unmodified chitosan films. On the other hand, this study reports the beneficial effects of the CMF on salmon samples stored at $5{ }^{\circ} \mathrm{C}$, especially maintaining the luminosity values closer to those of fresh salmon and by keeping the samples with lower TVB-N, pH values and bacterial counts for a longer period of time, with the samples remaining acceptable between the 4th and 7th days of storage.

The CMF revealed a great potential since it was placed on the upper surface of salmon only and even so showed a markedly positive effect. Moreover, CMF could also be suitable for packaging other type of food such as meat. Nevertheless, scale-up tests regarding this type of packaging are mandatory to assess its commercial and economic viability.

This type of packaging application could also be a sustainable alternative to petroleum-based plastic materials that are not biodegradable. The production of these packages will allow adding value to the by-products of several industries and also increasing the shelf-life of food products.

\section{Acknowledgments}

The author Rui M. S. Cruz would like to thank to Fundação para a Ciência e a Tecnologia (grant SFRH/BPD/70036/2010).

\section{References}

Aizpurua-Olaizola, O., Navarro, P., Vallejo, A., Olivares, M., Etxebarria, N., \& Usobiaga, A. (2016). Microencapsulation and storage stability of polyphenols from Vitis vinifera grape wastes. Food Chemistry, 190, 614-621.

Arancibia, M. Y., Alemán, A., López-Caballero, M. E., Gómez-Guillén, M. C., \& Montero, P. (2015). Development of active films of chitosan isolated by mild extraction with added protein concentrate from shrimp waste. Food Hydrocolloids, 43, 91-99.

ASTM E96-92 (1990). Standard test methods for water vapor transmission of materials
Annual book of ASTM. Philadelphia, PA: American Society for Testing \& Materials. ASTM D3985-02 (2002). Standard test method for oxygen gas transmission rate through plastic film and sheeting using a coulometric sensor. Annual book of ASTM. Philadelphia, PA: American Society for Testing \& Materials.

Bansode, S. S., Banarjee, S. K., Gaikwad, D. D., Jadhav, S. L., \& Thorat, R. M. (2010). Microencapsulation: A review. International Journal of Pharmaceutical Sciences Review and Research, 1, 38-43.

Bonilla, J., Fortunati, E., Atarés, L., Chiralt, A., \& Kenny, J. M. (2014). Physical, structural and antimicrobial properties of poly vinyl alcohol chitosan biodegradable films. Food Hydrocolloids, 35, 463-470.

Bourdon, A. I., Pinheiro, A. C., Cerqueira, M. A., Rocha, C. M. R., Avides, M. C., Quintas, M. C. A., et al. (2011). Physico-chemical characterization of chitosan-based edible films incorporating bioactive compounds of different molecular weight. Journal of Food Engineering, 106, 111-118.

Cerqueira, M. A., Lima, A. M., Souza, B. W. S., Teixeira, J. A., Moreira, R. A., \& Vicente, A A. (2009a). Functional polysaccharides as edible coatings for cheese. Journal of Agricultural and Food Chemistry, 57, 1456-1462.

Cerqueira, M. A., Lima, A. M., Teixeira, J. A., Moreira, R. A., \& Vicente, A. A. (2009b). Suitability of novel galactomannans as edible coatings for tropical fruits. Journal of Food Engineering, 94, 372-378.

Corrales, M., Fernández, A., \& Han, J. H. (2014). Antimicrobial packaging systems. In J. H. Han (Ed.). Innovations in food packaging (pp. 133-170). ( $2^{\text {nd }}$ ed.). London: Academic Press.

Costa, J. M. G., Borges, S. V., Hijo, A. A. C. T., Silva, E. K., Marques, G. R., Cirillo, M.Â., et al. (2013). Matrix structure selection in the microparticles of essential oil oregano produced by spray dryer. Journal of Microencapsulation, 30, 717-727.

Cuq, B., Gontard, N., Cuq, J. L., \& Guilbert, S. (1996). Functional properties of myofibrillar protein based biopackaging as affected by film thickness. Journal of Food Science, 61, 580-584.

Elsabee, M. Z., \& Abdou, E. S. (2013). Chitosan based edible films and coatings: A review. Materials Science \& Engineering C, 33, 1819-1841.

Estevinho, B. N., Rocha, F., Santos, L., \& Alves, A. (2013). Microencapsulation with chitosan by spray drying for industry applications - a review. Trends in Food Science \& Technology, 31, 138-155.

Fabra, M. J., López-Rubio, A., \& Lagaron, J. M. (2014). Biopolymers for food packaging applications. In M. R. Aguilar, \& J. S. Román (Eds.). Smart polymers and their applications (pp. 476-509). Cambridge: Woodhead Publishing Limited.

Fang, Z., \& Bhandari, B. (2012). Spray drying, freeze drying and related processes for food ingredient and nutraceutical encapsulation. In N. Garti, \& D. J. McClements (Eds.). Encapsulation technologies and delivery systems for food ingredients and nutraceuticals (pp. 73-109). Cambridge: Woodhead Publishing Limited.

Flores-López, M. L., Cerqueira, M. A., Jasso de Rodríguez, D., \& Vicente, A. A. (2015). Perspectives on utilization of edible coatings and nano-laminate coatings for extension of postharvest storage of fruits and vegetables. Food Engineering Reviews, 8, 292-305.

Hosseini, S. F., Rezaei, M., Zandi, M., \& Farahmandghavi, F. (2015a). Bio-based composite edible films containing Origanum vulgare L. essential oil. Industrial Crops and Products, 67, 403-413.

Hosseini, S. F., Rezaei, M., Zandi, M., \& Farahmandghavi, F. (2015b). Fabrication of bionanocomposite films based on fish gelatin reinforced with chitosan nanoparticles. Food Hydrocolloids, 44, 172-182.

Hui, P. C.-L., Wang, W.-Y., Kan, C.-W., Ng, F. S.-F., Zhou, C.-E., Wat, E., et al. (2013). Preparation and characterization of chitosan/sodium alginate (CSA) microcapsule containing Cortex Moutan. Colloids and Surfaces A: Physicochemical and Engineering Aspects, 434, 95-101.

Imran, M., Klouj, A., Revol-Junelles, A., \& Desobry, S. (2014). Controlled release of nisin from HPMC, sodium caseinate, poly-lactic acid and chitosan for active packaging applications. Journal of Food Engineering, 143, 178-185.

IPQ. NP 2930:2009 (2009). [Produtos da pesca e da aquicultura; Determinação do teor de azoto básico volátil total (ABVT); Método de Conway], Fishery and aquaculture products; Determination of total volatile basic nitrogen content (TVB-N); Conway method; Pub. L. $N^{\circ}$. NP 2930. (Costa Caparica, Portugal).

Jiang, T., Deng, M., James, R., Nair, L. S., \& Laurencin, C. T. (2014). Micro- and nanofabrication of chitosan structures for regenerative engineering. Acta Biomaterials, 10, 1632-1645.

Jouki, M., Mortazavi, S. A., Yazdi, F. T., \& Koocheki, A. (2014). Characterization of antioxidant-antibacterial quince seed mucilage films containing thyme essential oil. Carbohydrate Polymers, 99, 537-546.

Li, Y., Ai, L., Yokoyama, W., Shoemaker, C. F., Wei, D., Ma, J., et al. (2013b). Properties of chitosan-microencapsulated orange oil prepared by spray-drying and its stability to detergents. Journal of Agricultural and Food Chemistry, 13, 3311-3319.

Li, T., Li, J., Hu, W., \& Li, X. (2013a). Quality enhancement in refrigerated red drum (Sciaenops ocellatus) fillets using chitosan coatings containing natural preservatives. Food Chemistry, 138, 821-826.

Li, J., Miao, J., Wu, J., Chen, S., \& Zhang, Q. (2014). Preparation and characterization of active gelatin-based films incorporated with natural antioxidants. Food Hydrocolloids, $37,166-173$.

Martins, J. T., Cerqueira, M. A., \& Vicente, A. A. (2012). Influence of a-tocopherol on physicochemical properties of chitosan-based films. Food Hydrocolloids, 27, 220-227.

Ma, J., \& Sahai, Y. (2013). Chitosan biopolymer for fuel cell applications. Carbohydrate Polymers, 92, 955-975.

McHugh, T. H., Avena-Bustillos, R. J., \& Krochta, J. M. (1993). Hydrophilic edible film: Modified procedure for water vapor permeability and explanation of thickness effects. Journal of Food Science, 58, 899-903.

Monitoring \& Surveillance Series (2010). Microbiological quality of raw chicken fillets that are sold loose, but were previously distributed in gas flushed packaging (10NS3). 
Food Safety, 1-10.

Nazzaro, F., Orlando, P., Fratianni, F., \& Coppola, R. (2012). Microencapsulation in food science and biotechnology. Current Opinion in Biotechnology, 23, 182-186.

Nesterenko, A., Alric, I., Silvestre, F., \& Durrieu, V. (2013). Vegetable proteins in microencapsulation: A review of recent interventions and their effectiveness. Industrial Crops and Products, 42, 469-479.

Nicorescu, I., Nguyen, B., Chevalier, S., \& Orange, N. (2014). Effects of pulsed light on the organoleptic properties and shelf-life extension of pork and salmon. Food Control, $144,138-145$.

Nowzari, F., Shábanpour, B., \& Ojagh, S. M. (2013). Comparison of chitosan-gelatin composite and bilayer coating and film effect on the quality of refrigerated rainbow trout. Food Chemistry, 141, 1667-1672.

Ojagh, S. M., Rezaei, M., Razavi, S. H., \& Hosseini, S. M. H. (2010). Development and evaluation of a novel biodegradable film made from chitosan and cinnamon essential oil with low affinity toward water. Food Chemistry, 122, 161-166.

Pinheiro, A. C., Cerqueira, M. A., Souza, B. W. S., Martins, J. T., Teixeira, J. A., \& Vicente, A. A. (2010). [Utilização de revestimentos/filmes edíveis para aplicações alimentares]. Use of edible coatings/films for food applications. Boletim de Biotecnologia.

Qiu, X., Chen, S., Liu, G., \& Yang, Q. (2014). Quality enhancement in the Japanese sea bass (Lateolabrax japonicas) fillets stored at $4{ }^{\circ} \mathrm{C}$ by chitosan coating incorporated with citric acid or licorice extract. Food Chemistry, 162, 156-160.

Ramos, M., Beltrán, A., Peltzer, M., Valente, A. J. M., \& Garrigós, M. D. C. (2014). Release and antioxidant activity of carvacrol and thymol from polypropylene active packaging films. LWT - Food Science and Technology, 58, 470-477.

Rao, M. S., Kanatt, S. R., Chawla, S. P., \& Sharmam, A. (2010). Chitosan and guar gum composite films: Preparation, physical, mechanical and antimicrobial properties. Carbohydrate Polymers, 82, 1243-1247.

Reddy, G. V. B., Sen, A. R., Nair, P. N., Reddy, K. S., Reddy, K. K., \& Kondaiah, N. (2013). Effects of grape seed extract on the oxidative and microbial stability of restructured mutton slices. Meat Science, 95, 288-294.

Regulation (EC) No 2074/2005. Official Journal of the European union, 27-59.

Rosa, C. G., Borges, C. D., Zambiazi, R. C., Nunes, M. R., Benvenutti, E. V., Suzane, R. L., ... Rutz, J. K. (2013). Microencapsulation of gallic acid in chitosan, $\beta$-cyclodextrin and xanthan. Industrial Crops and Products, 46, 138-146.

Rubilar, J. F., Cruz, R. M. S., Khmelinskii, I., \& Vieira, M. (2013b). Effect of antioxidant and optimal antimicrobial mixtures of carvacrol, grape seed extract and chitosan on different spoilage microorganisms and their application as coatings on different food matrices. International Journal of Food Studies, 2, 22-38.

Rubilar, J. F., Cruz, R. M. S., Silva, H. D., Vicente, A. A., Khmelinskii, I., \& Vieira, M. C. (2013a). Physico-mechanical properties of chitosan films with carvacrol and grape seed extract. Journal of Food Engineering, 115, 466-474.

Ruiz-Navajas, Y., Viuda-Martos, M., Sendra, E., Perez-Alvarez, J. A., \& Fernández-López, J. (2013). In vitro antibacterial and antioxidant properties of chitosan edible films incorporated with Thymus moroderi or Thymus piperella essential oils. Food Control, 30, 386-392.

Sallam, K. I. (2007). Antimicrobial and antioxidant effects of sodium acetate, sodium lactate, and sodium citrate in refrigerated sliced salmon. Food Control, 18, 566-575. Sansone, F., Picerno, P., Mencherini, T., Porta, A., Lauro, M. R., Russo, P., et al. (2014). Technological properties and enhancement of antifungal activity of a Paeonia rockii extract encapsulated in a chitosan-based matrix. Journal of Food Engineering, 120, 260-267.

Sathivel, S., Liu, Q., Huang, J., \& Prinyawiwatkul, W. (2007). The influence of chitosan glazing on the quality of skinless pink salmon (Oncorhynchus gorbuscha) fillets during frozen storage. Journal of Food Engineering, 83, 366-373.

Silva-Weiss, Bifani, V., Ihl, M., Sobral, P. J. A., \& Gómez-Guillén, M. C. (2013). Structural properties of films and rheology of film-forming solutions based on chitosan and chitosan-starch blend enriched with murta leaf extract. Food Hydrocolloids, 31, $458-466$.

Soares, N. M. F., Oliveira, M. S. G., \& Vicente, A. A. (2015). Effects of glazing and chitosan-based coating application on frozen salmon preservation during six-month storage in industrial freezing chambers. LWT - Food Science and Technology, 61, 524-531.

Sobral, P. J. A., Menegalli, F. C., Hubinger, M. D., \& Roques, M. A. (2001). Mechanical, water vapor barrier and thermal properties of gelatin based edible films. Food Hydrocolloids, 15, 423-432.

Song, H., Yu, W., Gao, M., Liu, X., \& Ma, X. (2013). Microencapsulated probiotics using emulsification technique coupled with internal or external gelation process. Carbohydrate Polymers, 96, 181-189.

Souza, B. W. S., Cerqueira, M. A., Ruiz, H. A., Martins, J. T., Casariego, A., Teixeira, J. A., et al. (2010). Effect of chitosan-based coatings on the shelf life of salmon (Salmo salar). Journal of Agricultural and Food Chemistry, 58, 11456-11462.

Terra, X., Valls, J., Vitrac, X., Mérrilon, J., Arola, L., Ardèvol, A., ... Blay, M. (2007). Grape-seed procyanidins act as anti-inflammatory agents in endotoxin-stimulated raw 264.7 macrophages by inhibiting NFkB signaling pathway. Journal of Agricultural and Food Chemistry, 55, 4357-4365.

Vatavali, K., Karakosta, L., Nathanailides, C., Georgantelis, D., \& Kontominas, M. G. (2013). Combined effect of chitosan and oregano essential oil dip on the microbiological, chemical, and sensory attributes of red porgy (Pagrus pagrus) stored in ice. Food and Bioprocess Technology, 6, 3510-3521.

Vodnar, D. C. (2012). Inhibition of Listeria monocytogenes ATCC 19115 on ham steak by tea bioactive compounds incorporated into chitosan-coated plastic films. Chemistry Central Journal, 6, 74.

Wu, J., Ge, S., Liu, H., Wang, S., Chen, S., Wang, J., ... Zhang, Q. (2014). Properties and antimicrobial activity of silver carp (Hypophthalmichthys molitrix) skin gelatin-chitosan films incorporated with oregano essential oil for fish preservation. Food Packaging and Shelf Life, 2, 7-16.

Wu, Q. X., \& Yao, S. J. (2013). Novel NaCS-CS-PPS microcapsules as a potential enzymetriggered release carrier for highly-loading 5-ASA. Colloids and Surfaces. B, Biointerfaces, 109, 147-153.

Yamakoshi, J., Kataoka, S., Koga, T., \& Ariga, T. (1999). Proanthocyanidin-rich extract from grape seeds attenuates the development of aortic atherosclerosis in cholesterolfed rabbits. Atherosclerosis, 142, 139-149. 